\title{
Publisher Correction to: Frontiers of Business Research in China
}

\author{
Frontiers of Business Research in China
}

The original article can be found online at https://doi.org/10.1186/ s11782-019-0070-1

Correspondence: info@

biomedcentral.com

London, UK
An error occurred during the publication of the below two articles in Frontiers of Business Research in China. They were published in volume 14 with incorrect citation number.

In this correction article the old and new citation metadata is published in Table 1.

Table 1 Overview of incorrect and correct citation metadata

\begin{tabular}{|c|c|c|c|c|}
\hline DOI & $\begin{array}{l}\text { Incorrect volume } \\
\text { number }\end{array}$ & $\begin{array}{l}\text { Correct volume } \\
\text { number }\end{array}$ & $\begin{array}{l}\text { Incorrect article } \\
\text { number }\end{array}$ & $\begin{array}{l}\text { Correct article } \\
\text { number }\end{array}$ \\
\hline https://doi.org/10.1186/s11782-019-0067-9 & 14 & 13 & 1 & 21 \\
\hline https://doi.org/10.1186/s11782-019-0070-1 & 14 & 13 & 2 & 22 \\
\hline
\end{tabular}

The original articles have been updated. The publisher apologizes for the inconvenience caused to our authors and readers.

Received: 15 January 2020 Accepted: 15 January 2020

Published online: 05 February 2020

\section{Submit your manuscript to a SpringerOpen ${ }^{\odot}$} journal and benefit from:

- Convenient online submission

- Rigorous peer review

- Open access: articles freely available online

- High visibility within the field

- Retaining the copyright to your article

Submit your next manuscript at $>$ springeropen.com 